\title{
Pengaruh Penambahan Bekatul Terhadap Kadar Serat, Aktivitas Antioksidan dan Sifat Organoleptik Minuman Kedelai
}

\author{
Nurlitta Shafitri*1 $^{1}$, A'imatul Fauziyah ${ }^{1}$, Luh Desi Puspareni ${ }^{1}$ \\ ${ }^{1}$ Program Studi Ilmu Gizi, Fakultas Ilmu Kesehatan, Universitas Pembangunan Nasional Veteran Jakarta, \\ Indonesia
}

Author's Email Correspondence (*): nurlittashafitri@upnvj.ac.id (081380416878)

\begin{abstract}
Abstrak
Hiperkolesterol merupakan kondisi kadar kolesterol dalam darah melebihi batas normal ( $>240 \mathrm{mg} / \mathrm{dl}$ ). Salah satu alternatif pencegahan hiperkolesterol adalah dengan meningkatkan asupan serat dan antioksidan. Bekatul merupakan jenis pangan tinggi serat dan kaya antioksidan. Kedelai merupakan jenis pangan tinggi isoflavon yang mampu menurunkan hiperkolesterol. Penelitian ini bertujuan untuk menganalisis pengaruh penambahan bekatul terhadap kadar serat, aktivitas antioksidan dan sifat organoleptik minuman kedelai serta menentukan formula terpilih dan menganalisis kandungan gizi formula terpilih. Desain penelitian yang digunakan adalah Rancangan Acak Lengkap (RAL) satu faktor berupa empat perlakuan dengan penambahan bekatul sebesar F0 (0\%), F1 (6\%), F2 (8\%) dan F3 (10\%). Analisis uji organoleptik menggunakan uji Kruskal Wallis dan dilanjutkan dengan uji Mann Whitney jika terdapat perbedaan. Analisis serat pangan dan aktivitas antioksidan menggunakan uji ANOVA dan dilanjutkan dengan uji Duncan jika terdapat perbedaan signifikan. Hasil analisis uji organoleptik menunjukkan bahwa penambahan bekatul berpengaruh nyata $(\mathrm{p}<0,05)$ terhadap tingkat kesukaan panelis pada parameter warna, aroma, tekstur dan rasa minuman kedelai. Hasil analisis serat pangan dan aktivitas antioksidan menunjukkan bahwa penambahan bekatul berpengaruh nyata $(p<0,05)$ terhadap kadar serat pangan dan aktivitas antioksidan minuman kedelai. Formula terpilih pada penelitian ini adalah F3 dengan penambahan bekatul 10\% karena memiliki kandungan gizi yang lebih unggul dibanding formula lain, yaitu kadar serat pangan 10,23 gram, aktivitas antioksidan 3094.18 ppm, kadar protein 1,80\%, kadar lemak 1,64\%, kadar karbohidrat 6,49\%, kadar abu 0,73\% dan kadar air 89,34\%.
\end{abstract}

Kata Kunci: Minuman Kedelai; Bekatul; Serat Pangan; Aktivitas Antioksidan,

How to Cite:

Shafitri, N., Fauziyah, A., Puspareni, L., \& Nasrulloh, N. (2021). Pengaruh Penambahan Bekatul Terhadap Kadar Serat, Aktivitas Antioksidan dan Sifat Organoleptik Minuman Kedelai. Ghidza: Jurnal Gizi Dan Kesehatan, 5(1), 107 - 119. https://doi.org/10.22487/ghidza.v5i1.233

Published by:

Tadulako University

Address:

Soekarno Hatta KM 9. Kota Palu, Sulawesi Tengah, Indonesia.

Phone: +628525357076

Email: ghidzajurnal@gmail.com
Article history :

Received : 23032021

Received in revised form : 13072021

Accepted : 17072021

Available online 21072021 


\begin{abstract}
Hypercholesterolemia is a condition where cholesterol levels in the blood exceed normal limits $(>240$ $\mathrm{mg} / \mathrm{dl}$ ). One of the alternative ways to prevent hypercholesterol is by increasing fiber and antioxidant intake. Rice brans are high in fiber and rich in antioxidants. Soybeans are high in isoflavones which can reduce hypercholesterolemia. This study aims to analyze the effect of rice bran addition on fiber levels, antioxidant activity and organoleptic test of soybean drink and determine the selected formula and analyze the nutritional content of selected formulas. This research is an experimental study with a complete randomized design (CDR) one factor in the form of four treatments with the addition of rice bran by F0 (0\%), F1 (6\%), F2 (8\%) and F3 (10\%). Organoleptic test data was analyzed by using the Kruskal Wallis test and followed by using the Mann Whitney test if there were any significant differences. Food fiber test data and antioxidant activity were analyzed with the ANOVA test and continued with Duncan's test if there are significant differences. The results of organoleptic test analysis showed that the addition of rice bran had a significant effect $(\mathrm{p}<0.05)$ on the panelist's preferred level on the parameters of color, flavor, texture and taste of soybean drink. The results of analysis of dietary fiber and antioxidant activity showed that the addition of rice bran has a real effect $(p<0.05)$ on food fiber levels and antioxidant activity of soybean drink. The formula selected in this study is F3 with the addition of $10 \%$ rice bran because it has more eminent nutrition than other formulas, which contains 10.23 grams food fiber, 3094.18 ppm antioxidant activity, $1.80 \%$ protein, $1.64 \%$ fat, $6.49 \%$ carbohydrate, $0.73 \%$ ash and $89.34 \%$ water
\end{abstract}

Keywords: Soybean Drinks; Rice Bran; Food Fiber; Antioxidant Activity

\title{
I. PENDAHULUAN
}

Kementerian Kesehatan Republik Indonesia menjelaskan hiperkolesterol merupakan kondisi kadar kolesterol dalam darah cenderung tinggi atau melebihi batas normal yaitu lebih dari $240 \mathrm{mg} / \mathrm{dl}$. Pada tahun 2013 proposi kadar kolesterol abnormal penduduk umur $\geq 15$ adalah sebesar 35,9\%. Hiperkoletserol merupakan faktor resiko yang dapat meningkatkan terjadinya aterosklerosis, penyakit jantung koroner, pankreatitis, diabetes melitus, gangguan tiroid, penyakit hepar dan penyakit ginjal (Fikri et al., 2010). Hiperkolesterol dapat memicu terjadinya penyakit kardiovaskuler yang merupakan salah satu jenis penyakit degeneratif dengan angka kematian cukup tinggi (Yani, 2015). Menurut perkiraan World Health Organization (WHO) pada tahun 2016, terdapat 17,9 juta orang meninggal akibat penyakit kardiovaskuler.

Terjadinya hiperkolesterol sangat berkaitan dengan gaya hidup. Sari \& Husna (2016) menyatakan bahwa gaya hidup tidak sehat dapat menyebabkan terjadinya hiperkolesterol. Adanya perubahan gaya hidup mengakibatkan pola dan atau kebiasaan makan sebagian besar masyarakat mengalami perubahan menjadi salah dan tidak sehat. Menurut Yoeantafara \& Martini (2017), sering mengonsumsi makanan tinggi lemak merupakan penyebab utama terjadinya peningkatan kadar kolesterol total dalam darah. Kolesterol yang berasal dari makanan disebut dengan kolesterol eksogen (Puspitasari, 2017). Selain kolesterol eksogen, terdapat kolesterol endogen atau kolesterol yang di produksi dari dalam sel tubuh terutama hati (Siregar, 2015).

Serat dan antioksidan memiliki mekanisme berbeda dalam menurunkan kolesterol. Mekanisme serat dalam menurunkan kolesterol berkaitan dengan pemecahan kolesterol endogen akibat ekskresi garam empedu yang merupakan produk akhir kolesterol. Menurut Santoso (2011), serat pangan dapat mengikat garam empedu dan akan dikeluarkan bersama feses. Ketika garam empedu dikeluarkan bersama feses, 
akan terjadi proses pemecahan kolesterol endogen untuk menggantikan garam empedu yang hilang. Dengan demikian, kadar kolesterol pada plasma darah akan berkurang dan tidak menyebabkan terjadinya penumpukan (Tuarita \& Sadek, 2017). Mekanisme antioksidan dalam menurunkan kolesterol berkaitan dengan pencegahan oksidasi asam lemak akibat adanya radikal bebas. Menurut Yunarto et al., (2019) terjadinya oksidasi asam lemak akan memudahkan kolesterol melewati dinding arteri dan meningkatkan jumlah kolesterol dalam darah. Antioksidan mampu menstabilkan radikal bebas dengan melengkapi elektron yang kurang pada radikal bebas (Selawa et al., 2013).

Salah satu jenis pangan tinggi antioksidan adalah kacang kedelai (Glycine max). Kacang kedelai dapat diolah menjadi minuman fungsional yaitu minuman kedelai yang terbuat dari bubuk (tepung) kedelai. Menurut Siburian (2014), kedelai mengandung isoflavon yang dapat menurunkan resiko terkena penyakit degeneratif. Dalam kasus hiperkolesterol, menurut Andriani (2016) isoflavon berperan sebagai antioksidan dan mampu meningkatkan HDL (high-density lipoprotein). Kandungan isoflavon pada kedelai bervariasi dari 128 - $380 \mathrm{mg}$ per 100 gram (Yulifianti et al., 2018). Meskipun tinggi antioksidan, kandungan serat pada tepung kedelai akan mengalami penurunan secara signifikan. Menurut Napitupulu et al (2013), dalam 100 gram tepung kedelai mengandung serat sebesar 3,2\%.

Bekatul merupakan salah satu bahan pangan dengan harga terjangkau dan produksinya cukup banyak di Indonesia sehingga mudah untuk didapatkan. Dalam 100 gram bekatul terkadung serat pangan sebesar 22,67 gram, serat kasar sebesar 11,4 gram dan serat larut air sebesar 24,15 (Aparecida et al., 2012). Bekatul mengandung berbagai komponen bioaktif seperti $\gamma$-oryzanol, asam fenolat dan vitamin $\mathrm{E}$ yang terbukti dapat memberikan efek fisiologis seperti anti-oksidatif dan anti-hiperkolesterolemia (Sookwong et al., 2016). Menurut Laokuldilok et al (2010) pada 100 gram bekatul terdapat $\gamma$-oryzanol sebesar 62,9\% dan asam fenolat sebesar 25,9\%. Meskipun unggul dari segi ekonomis dan kaya akan kandungan gizi, pemanfaatan bekatul menjadi olahan pangan masih terbatas dimana sebagian besar bekatul digunakan sebagai pakan ternak. Berdasarkan latar belakang tersebut, dengan adanya produk minuman kedelai dengan penambahan bekatul diharapkan dapat meningkatkan keanekaragaman produk pangan berbahan dasar pangan lokal. Selain itu, produk minuman kedelai dengan penambahan bekatul dinilai sangat potensial dalam menurunkan kolesterol.

\section{METHOD}

Penelitian ini merupakan penelitian eksperimental dengan desain Rancangan Acak Lengkap (RAL) satu faktor berupa empat perlakuan dengan penambahan bekatul sebesar F0 (0\%), F1 30 gram (6\%), F2 40 gram (8\%) dan F3 50 gram (10\%). Penelitian ini dilakukan selama empat bulan dari September 2020. Pembuatan sampel minuman kedelai dengan penambahan bekatul dilakukan di rumah peneliti. Analisis kadar serat pangan dilakukan di Laboratorium Saraswanti Indo Genetech (SIG) Bogor, analisis aktivitas antioksidan dilakukan di Laboratorium Terpadu UIN Syarif Hidayatullah Jakarta dan uji organoleptik dilakukan di Laboratorium Teknologi Pangan Fakultas Ilmu Kesehatan UPN Veteran Jakarta.

Alat yang digunakan dalam pembuatan bubuk (tepung) kedelai yaitu wadah, blender, timbangan, ayakan 60 dan 80 mesh. Alat analisis serat pangan yaitu neraca analitik, Erlenmeyer, corong Buchner, 
kertas saring dan kertas lakmus. Alat aktivitas antioksidan yaitu Erlenmeyer, neraca analitik, gelas beaker, gelas ukur, labu takar, spektrofotometer UV-Vis, penangas air dan kertas saring. Alat analisis kandungan gizi yaitu oven, neraca analitik, cawan aluminium dan porselen, eksikator, tang penjepit, pembakar bunsen, tanur, soxhlet, kertas saring, labu kjeldahl dan alat destilasi.

Bahan pembuatan minuman kedelai dengan penambahan bekatul adalah kedelai kering utuh dengan merk Super Indo, bekatul kemasan dengan merk Dr. Liem serta gula stevia cair dengan merk Drip Sweet. Bahan analisis serat pangan yaitu etanol 95\%, larutan $\mathrm{NaOH}$, larutan $\mathrm{HCL}, \mathrm{K} 2 \mathrm{SO} 4, \mathrm{H} 2 \mathrm{SO} 4$ dan aquades. Bahan analisis aktivitas antioksidan yaitu serbuk DPPH, etanol 96\%, metanol pro analysis dan aquades. Bahan analisis kandungan gizi yaitu kloroform, katalis campuran, asam sulfat pekat, aquades, $\mathrm{NaOH}$ dan larutan asam boraks.

Tahap pertama pada penelitian ini adalah pembuatan bubuk kedelai yaitu dengan melakukan sortasi kedelai, mencuci kedelai hingga bersih, mengupas kulit kedelai dan menjemur kedelai hingga kering. Selanjutnya kedelai diblender sampai teksturnya menjadi bubuk. Ayak bubuk kedelai dengan ayakan 60 mesh dan ayakan 80 mesh agar didapatkan bubuk kedelai yang lebih halus. Tahap kedua adalah pembuatan produk yaitu mencampurkan bubuk kedelai dengan formulasi tepung bekatul yang telah ditentukan $(6 \%, 8 \%, 10 \%)$. Setelah itu seduh dengan $473 \mathrm{ml}$ air panas dan tambahkan $2 \mathrm{ml}$ gula stevia cair lalu aduk hingga tercampur. Berdasarkan trial and error, penambahan air sebanyak $473 \mathrm{ml}$ dan gula stevia sebanyak $2 \mathrm{ml}$ dirasa sudah cukup dari segi kekentalan dan kemanisannya.

Uji serat pangan dilakukan dengan menimbang 1 gram sampel dan dimasukkan ke dalam Erlenmeyer $300 \mathrm{cc}$. Tambahkan H2SO4 0,3 N lalu didihkan di atas penangas air selama 30 menit dengan sedikit digoyangkan. Larutan dalam Erlenmeyer disaring menggunakan corong Buchner yang telah dialasi dengan kertas saring. Bilas Erlenmeyer dengan air didih lalu masukkan residu yang terdapat pada kertas saring ke dalam Erlenmeyer. Cuci residu yang tertinggal di kertas saring dengan $200 \mathrm{ml} \mathrm{NaOH}$ didih agar seluruh residu masuk ke dalam Erlenmeyer. Didihkan kembali sampel selama 30 menit dan disaring lalu dicuci dengan larutan K2SO4 10\%. Cuci residu dengan alkohol 95\% lalu keringkan kertas saring pada suhu $105^{\circ} \mathrm{C}$ selama 15 menit dan kemudian ditimbang.

Uji aktivitas antioksidan dilakukan menggunakan metode DPPH. Untuk mendapatkan larutan stock DPPH, larutkan 5mg serbuk DPPH dalam 100ml methanol pro analysis. Campurkan $1 \mathrm{ml}$ sampel dan $1 \mathrm{ml}$ DPPH dalam tabung reaksi lalu encerkan dengan $2 \mathrm{ml}$ methanol. Lakukan inkubasi selama 30 menit dalam penangas air pada suhu $37^{\circ} \mathrm{C}$ hingga terjadi perubahan warna. Setelah itu uji nilai absorbansi pada sampel yang telah di inkubasi menggunakan spektrofotometer UV-Vis dengan panjang gelombang $517 \mathrm{~nm}$. Adanya antioksidan ditandai dengan terbentuknya warna kuning pada sampel.

Uji organoleptik yang dilakukan berupa uji hedonik atau uji kesukaan kepada 30 panelis semi terlatih (SNI 01-2346-2006). Adapun panelis pada penelitian ini yaitu mahasiswa S1 Ilmu Gizi UPN Veteran Jakarta semester 5 dan semester 7 yang sudah mendapatkan mata kuliah Teknologi Pangan. Panelis diminta untuk menilai poduk dalam kategori warna, aroma, tekstur dan rasa dengan menulis skor 1 jika amat tidak suka, skor 2 jika tidak suka, skor 3 jika biasa saja, skor 4 jika suka dan skor 5 jika sangat suka pada formulir uji organoleptik. 
Hasil uji organoleptik dianalisis dengan uji Kruskal Wallis dan dilanjutkan dengan uji Mann Whitney. Uji kadar serat dan aktivitas antioksidan dianalisis menggunakan uji dan dilanjutkan dengan uji Duncan. Penentuan formula terpilih dilakukan dengan metode MPE (Metode Perbandingan Eksponensial) yang ditentukan dari hasil uji organoleptik, serat pangan dan aktivitas antioksidan.

\section{HASIL}

\section{Kadar Serat}

Pada F0 minuman kedelai dengan penambahan bekatul tekandung serat pangan sebesar $1.44 \pm 0.28$ per 100 gram, pada F1 terkandung serat pangan sebesar $2.34 \pm 0.44$ per 100 gram, pada F2 terkandung serat pangan sebesar $3.23 \pm 0.10$ per 100 gram dan pada F3 terkandung serat pangan sebesar $3.61 \pm 0.14$ per 100 gram. Pada penelitian ini F3 memiliki kadar serat pangan tertinggi dan F0 memiliki kadar serat pangan terendah.

Tabel 1. Kadar Serat Minuman Kedelai dengan Penambahan Bekatul

\begin{tabular}{ccccc}
\hline Parameter & \multicolumn{4}{c}{ Hasil Kadar Serat Pangan } \\
\cline { 2 - 5 } & F0 & F1 & F2 & F3 \\
\hline Kadar Serat Pangan (\%) & $1.44 \pm 0.28^{\mathrm{a}}$ & $2.34 \pm 0.44^{\mathrm{b}}$ & $3.23 \pm 0.10^{\mathrm{c}}$ & $3.61 \pm 0.14^{\mathrm{c}}$ \\
\hline
\end{tabular}

Keterangan: Angka-angka pada baris yang sama kemudian diikuti oleh notasi huruf yang sama berarti tidak berbeda nyata pada taraf uji 5\% (uji Duncan)

Hasil uji ANOVA menunjukkan bahwa penambahan bekatul berpengaruh nyata $(\mathrm{p}=0.005)$ terhadap peningkatan kadar serat pangan pada minuman kedelai. Oleh karena itu perlu dilakukan uji Duncan untuk melihat kelompok yang secara signifikan memiliki perbedaan. Hasil uji lanjut Duncan menunjukkan bahwa kadar serat pangan F0 sebagai kelompok kontrol berbeda secara nyata dengan kadar serat pangan kelompok perlakuan F1, F2 dan F3. Kadar serat pangan F1 berbeda secara nyata dengan kadar serat pangan F2 dan F3. Kadar serat pangan F2 tidak berbeda secara nyata dengan F3.

\section{Aktivitas Antioksidan}

Minuman kedelai dengan penambahan bekatul memiliki aktivitas antioksidan sebesar $12489.73 \pm$ 505.49 pada F0, aktivitas antioksidan sebesar $15275.10 \pm 2544.85$ pada F1, aktivitas antioksidan sebesar $4562.38 \pm 1342.68$ pada F2 dan aktivitas antioksidan sebesar $3094.18 \pm 389.65$ pada F3. Berdasarkan analisis aktivitas antioksidan, disimpulkan bahwa F3 pada penelitian ini F3 memiliki aktivitas antioksidan terkuat dan F1 memiliki aktivitas antioksidan terlemah. 
Tabel 2. Aktivitas Antioksidan Minuman Kedelai dengan Penambahan Bekatul

\begin{tabular}{ccccc}
\hline \multirow{2}{*}{ Parameter } & \multicolumn{4}{c}{ Hasil Aktivitas Antioksidan } \\
\cline { 2 - 4 } & F0 & F1 & F2 & F3 \\
\hline $\begin{array}{c}\text { Aktivitas Antioksidan } \\
\text { (ppm) }\end{array}$ & $12489.73 \pm 505.49^{\mathrm{a}}$ & $15275.10 \pm 2544.85^{\mathrm{a}}$ & $4562.38 \pm 1342.68^{\mathrm{b}}$ & $3094.18 \pm 389.65^{\mathrm{b}}$ \\
\hline
\end{tabular}

Keterangan: Angka-angka pada baris yang sama kemudian diikuti oleh notasi huruf yang sama berarti tidak berbeda nyata pada taraf uji 5\% (uji Duncan)

Berdasarkan hasil uji ANOVA didapatkan bahwa terdapat perbedaan nyata $(\mathrm{p}=0.003)$ antara keempat formula terhadap aktivitas antioksidan sehingga perlu dilakukan uji Duncan untuk melihat kelompok yang secara signifikan memiliki perbedaan. Hasil uji lanjut Duncan menunjukkan bahwa aktivitas antioksidan F0 tidak berbeda secara nyata terhadap aktivitas antioksidan F1, tetapi berbeda secara nyata terhadap aktivitas antioksidan F2 dan F3. Aktivitas antioksidan F1 berbeda secara nyata dengan aktivitas antioksidan F2 dan F3.

\section{Uji Organoleptik}

Uji organoleptik dilakukan kepada 30 panelis semi terlatih yaitu mahasiswa S1 Ilmu Gizi UPN Veteran Jakarta semester 5 dan semester 7 serta sudah mendapatkan mata kuliah Teknologi Pangan. Panelis diminta untuk melakukan uji hedonik dengan cara memberi skor 1-5 pada produk minuman kedelai dengan penambahan bekatul dari parameter warna, aroma, tekstur dan rasa dengan klasifikasi (1) amat tidak suka, (2) tidak suka, (3) biasa saja, (4) suka dan (5) sangat suka. Hasil uji hedonik pada produk minuman kedelai dengan penambahan bekatul terdapat pada Tabel 3.

Tabel 3. Hasil Uji Hedonik Minuman Kedelai dengan Penambahan Bekatul

\begin{tabular}{ccccc}
\hline \multirow{2}{*}{ Parameter } & \multicolumn{4}{c}{ Nilai Median Uji Hedonik } \\
\cline { 2 - 5 } & F0 & F1 & F2 & F3 \\
\hline Warna & $4.50(3-5) \mathrm{a}$ & $3.00(1-4) \mathrm{b}$ & $2.50(1-5) \mathrm{b}$ & $3.00(1-5) \mathrm{b}$ \\
\hline Aroma & $4.00(1-5) \mathrm{a}$ & $3.00(1-5) \mathrm{ab}$ & $3.00(1-4) \mathrm{bc}$ & $3.00(1-5) \mathrm{c}$ \\
\hline Tekstur & $4.00(1-5) \mathrm{a}$ & $4.00(2-5) \mathrm{ab}$ & $3.00(1-5) \mathrm{b}$ & $3.00(1-5) \mathrm{b}$ \\
\hline Rasa & $4.00(2-5) \mathrm{a}$ & $3.00(1-5) \mathrm{b}$ & $3.00(1-5) \mathrm{bc}$ & $2.00(1-4) \mathrm{c}$ \\
\hline
\end{tabular}

Setelah dilakukan uji hedonik, data diolah menggunakan uji Kruskal Wallis untuk melihat normalitas sebaran data. Pada hasil uji normalitas didapatkan bahwa sebaran data tidak normal sehingga perlu dilakukan uji lanjutan Mann Whitney untuk melihat signifikansi perbedaan.

\section{Warna}

Berdasarkan uji hedonik didapatkan nilai median F0 adalah yang tertinggi, nilai median F1 dan F3 adalah sama dan nilai median pada F2 lebih rendah dari formula lain. Hasil uji Kruskal Wallis 
menunjukkan adanya pengaruh secara nyata susu kedelai dengan penambahan bekatul $(\mathrm{p}=0.000)$ terhadap tingkat kesukaan panelis pada parameter warna sehingga dilakukan uji lanjutan Mann Whitney.

\section{Aroma}

Berdasarkan uji hedonik didapatkan nilai median F0 adalah yang tertinggi dan nilai median F1, F2 dan F3 adalah sama. Berdasarkan uji Kruskal Wallis didapatkan adanya pengaruh secara nyata minuman kedelai dengan penambahan bekatul $(\mathrm{p}=0.000)$ terhadap tingkat kesukaan panelis pada parameter aroma sehingga dilakukan Uji Mann Whitney sebagai uji lanjutan.

\section{Tekstur}

Berdasarkan uji hedonik didapatkan nilai median F0 dan F1 adalah sama serta nilai median F2 dan F3 adalah sama. Berdasarkan hasil uji Kruskal Wallis didapatkan adanya pengaruh secara nyata minuman kedelai dengan penambahan bekatul $(\mathrm{p}=0.008)$ terhadap tingkat kesukaan panelis pada aspek tekstur sehingga dilakukan uji lanjutan Mann Whitney.

\section{Rasa}

Berdasarkan uji hedonik didapatkan nilai median tertinggi pada parameter rasa adalah F0 dan nilai median terendah adalah F3. Sedangkan nilai median pada F1 dan F2 adalah sama. Hasil uji Kruskal Wallis menunjukkan adanya pengaruh secara nyata minuman kedelai dengan penambahan bekatul $(\mathrm{p}=0.000)$ terhadap tingkat kesukaan panelis pada parameter rasa sehingga dilakukan uji lanjutan Mann Whitney.

\section{Uji Proksimat Formula Terpilih}

Melalui metode perbandingan eksponensial (MPE) didapatkan bahwa F3 sebagai kelompok perlakuan dengan penambahan bekatul $10 \%$ memiliki skor terkecil sehingga dapat disimpulkan bahwa formula tersebut merupakan formula terpilih pada penelitian ini. Hasil uji proksimat pada F3 terdapat pada Tabel 4 .

Tabel 4. Hasil Uji Proksimat Minuman Kedelai dengan Penambahan Bekatul

\begin{tabular}{ccccc}
\hline Parameter & Formula Terpilih & \multicolumn{2}{c}{ SNI Susu Kedelai* } & \multicolumn{2}{c}{$\begin{array}{c}\text { Aman dan } \\
\text { Minuman }\end{array}$} & Hardjo** \\
\hline Protein (\%) & & min. 2,0 & min. 1,0 & $3,50 \mathrm{gr}$ \\
\hline Lemak Total (\%) & 1,80 & min. 1,0 & min. 0,30 & $2,50 \mathrm{gr}$ \\
\hline Energi dari Lemak (kkal/100 g) & 1,64 & - & - & - \\
\hline Energi Total (kkal/100 g) & 14,76 & - & - & $41,00 \mathrm{gr}$ \\
\hline Karbohidrat (\%) & 47,92 & - & - & $5,00 \mathrm{gr}$ \\
\hline Kadar Abu (\%) & 6,49 & - & - & - \\
\hline Kadar Air (\%) & 0,73 & - & - & - \\
\hline
\end{tabular}

Formula terpilih minuman kedelai dengan penambahan bekatul memiliki kadar protein 1,80\% sehingga jika dibandingkan dengan SNI maka telah memenuhi standar pada kategori minuman dan belum memenuhi standar pada kategori susu. Kadar lemak total formula terpilih minuman kedelai dengan penambahan bekatul yaitu sebesar 1,64\% sehingga telah memenuhi standar baik pada kategori minuman atau kategori susu. Formula terpilih minuman kedelai dengan penambahan bekatul memiliki energi dari 
lemak sebesar 14,76 kkal/100 gram, energi total sebesar 47,92 kkal/100 gram, karbohidrat sebesar 6,49\%, kadar abu sebesar $0,73 \%$ serta kadar air sebesar $89,34 \%$.

\section{PEMBAHASAN}

\section{Serat Pangan}

Serat pangan merupakan karbohidrat yang tidak dapat dicerna oleh enzim-enzim pencernaan. Menurut Luthfianto et al (2017), serat yang terdapat dalam bekatul sebagian besar terdiri atas karbohidrat seperti selulosa, hemiselulosa, pektin dan lignin. Hasil analisis kadar serat pangan menunjukkan bahwa F3 memiliki kadar serat pangan tertinggi dan F0 memiliki kadar serat pangan terendah. Hal tersebut sesuai dengan penelitian Hendrayati (2019) yang menyatakan bahwa semakin tinggi penambahan bekatul maka kadar serat pangan juga semakin meningkat. Sesuai dengan label acuan gizi yang dikeluarkan oleh BPOM RI (2016), suatu produk pangan dikatakan memenuhi klaim kaya serat jika mengandung serat pangan sebesar 6 gram per 100 gram dalam bentuk padat atau mengandung serat pangan sebesar 3 gram per 100 kkal dalam bentuk cair. Maka dapat disimpulkan bahwa F0 dan F1 minuman kedelai dengan penambahan bekatul belum memenuhi klaim kaya serat sedangkan F2 dan F3 minuman kedelai dengan penambahan bekatul telah memenuhi klaim kaya serat.

\section{Aktivitas Antioksidan}

Antioksidan diperlukan untuk menghambat reaksi oksidasi oleh radikal bebas atau menetralkan dan menghancurkan radikal bebas yang dapat menyebabkan kerusakan sel (Alfira, 2014). Menurut Widyasanti et al (2016) efektivitas suatu sampel dalam menangkal radikal bebas dari metode DPPH disebut dengan IC50 (Inhibitory Concentration). Pengertian IC50 adalah konsentrasi yang dapat merendam 50\% radikal bebas DPPH (Widyasanti et al., 2016). Suatu senyawa dikatakan sebagai antioksidan sangat kuat jika memiliki nilai IC50 kurang dari 50 ppm, kuat jika bernilai 50 - 100 ppm, sedang jika bernilai 150 ppm dan lemah jika bernilai 151 - 200 ppm (Tristantini et al., 2016). Menurut Widyasanti et al (2016), semakin kecil nilai IC50 maka semakin besar aktivitas antioksidannya.

Berdasarkan hasil analisis aktivitas antioksidan didapatkan bahwa terjadi kenaikan aktivitas antioksidan pada F1 dan penurunan aktivitas antioksidan F3. Hal tersebut ditunjukkan dengan aktivitas antioksidan pada F1 yaitu sebesar 15275.10 ppm dan aktivitas antioksidan pada F3 sebesar 3094.18 ppm. Salah satu faktor yang menyebabkan lemahnya aktivitas antioksidan adalah suhu pada proses pemasakan. Hal tersebut sesuai dengan penelitian Nur et al (2018) bahwa pada suhu lebih dari $100^{\circ} \mathrm{C}$ beberapa senyawa fenolik dan isoflavon akan terdegradasi yang dibuktikan dari menurunnya aktivitas antioksidan.

\section{Warna}

Warna sangat penting untuk segala jenis makanan atau minuman karena akan berpengaruh terhadap tingkat penerimaan panelis (Amir, 2018). Perbedaan warna yang timbul pada setiap formula disebabkan karena adanya penambahan konsentrasi bekatul yang berbeda-beda. Pada parameter warna, tingkat kesukaan panelis tertinggi berada pada F0 (kontrol) yang tidak mengandung bekatul sehingga memiliki warna putih gading khas kedelai. F1, F2 dan F3 sebagai kelompok perlakuan memiliki warna putih 
cenderung keruh yang disebabkan karena adanya penambahan bekatul. Hal tersebut sesuai dengan penelitian Amir (2018) dimana pembuatan susu bekatul dengan konsentrasi bekatul lebih sedikit yaitu pada formula 1 memperoleh nilai yang lebih tinggi dibandingkan formula lainnya. Hal tersebut menunjukkan bahwa semakin besar persentase penambahan bekatul maka akan menyebabkan menurunnya tingkat kesukaan terhadap suatu produk.

\section{Aroma}

Aroma merupakan salah satu faktor penentu yang mempengaruhi tingkat kesukaan panelis terhadap suatu produk. Menurut Amir (2018), aroma menentukan kelezatan suatu bahan makanan karena biasanya seseorang menilai lezat atau tidaknya suatu makanan berdasarkan aroma yang ditimbulkan. Pada parameter aroma, tingkat kesukaan panelis tertinggi berada pada F0 karena tidak mengandung bekatul dan memiliki aroma segar khas kedelai. F1, F2 dan F3 sebagai kelompok perlakuan memiliki aroma khas bekatul yaitu langu sehingga cenderung tidak disukai oleh panelis. Berdasarkan penelitian yang dilakukan oleh Wulandari \& Handasari (2010) pada pembuatan biskuit dengan penambahan tepung bekatul, didapatkan bahwa terdapat perbedaan aroma pada setiap penambahan bekatul terhadap biskuit. Penelitian tersebut menjelaskan bahwa biskuit dengan bekatul 0\% memiliki tingkat kesukaan yang lebih tinggi dari biskuit dengan bekatul 5\%, 10\% dan 15\%. Hal tersebut menunjukkan bahwa semakin besar persentase penambahan bekatul dalam suatu produk, maka akan berpengaruh terhadap tingkat kesukaan panelis terhadap aroma dari produk tersebut. Amir (2018) menjelaskan bahwa munculnya aroma khas bekatul disebabkan karena adanya minyak tokoferol yang terkandung dalam bekatul.

\section{Tekstur}

Tekstur merupakan sensasi tekanan yang dapat diamati dengan melihat dan dirasakan pada waktu digigit, dikunyah, ditelan ataupun diraba dengan jari (Aliyah, 2010). Pada penelitian ini, panelis memberikan penilaian berdasarkan tingkat kesukaan terhadap tekstur minuman kedelai dengan penambahan bekatul yang cenderung berpasir (sandy). F0 sebagai kelompok kontrol tidak mengandung bekatul sehingga memiliki tekstur halus khas minuman kedelai dan tidak berpasir. F1 memiliki tekstur sedikit berpasir namun masih dapat diterima dan cenderung disukai oleh panelis. F2 dan F3 memiliki tekstur lebih berpasir dibanding F1 tetapi masih dapat diterima dan dianggap biasa saja oleh panelis. Pada penelitian ini bekatul tidak homogen dengan kedelai sehingga mengakibatkan adanya butiran-butiran halus seperti pasir yang dirasakan oleh lidah. Hal tersebut sejalan dengan penelitian oleh Wijaya (2018) yaitu munculnya mouthfeel berpasir (sandy) diakibatkan karena adanya suatu bahan yang tidak tercampur secara merata.

\section{Rasa}

Rasa merupakan faktor penting lainnya yang sangat berpengaruh terhadap tingkat kesukaan panelis dan daya terima suatu produk. Triastini (2018) menjelaskan bahwa rasa merupakan persepsi biologis seperti sensasi yang dihasilkan oleh materi yang masuk ke mulut. Tingkat kesukaan panelis pada aspek rasa tertinggi yaitu berada pada F0 (kontrol) karena tidak mengandung bekatul. F0 sebagai memiliki rasa manis dan rasa khas kedelai. F1 dan F2 memiliki rasa agak pahit tetapi masih dapat diterima oleh panelis dan dianggap biasa saja. F3 merupakan formula dengan nilai terendah dimana F3 memiliki rasa pahit 
khas bekatul dan tidak disukai oleh panelis. Menurut Nadimin et al (2019), rasa pahit pada bekatul disebabkan karena adanya kandungan saponin bekatul, serta rasa khas bekatul muncul akibat kandungan minyaknya (tokol, tokoferol, tokotrienol). Selain itu Nataliningsih (2009) menjelaskan bahwa rasa kurang enak dan agak pahit pada bekatul disebabkan karena kandungan utamanya adalah karbohidrat dan serat.

\section{Takaran Saji}

Takaran saji merupakan jumlah produk pangan olahan yang wajar untuk dikonsumsi dalam satu kali makan, dinyatakan dalam satuan metrik atau ukuran rumah tangga yang sesuai (BPOM, 2016). Berdasarkan formula terpilih, minuman kedelai dengan penambahan bekatul memiliki takaran saji sebesar 275 ml. Pada F3 minuman kedelai dengan penambahan bekatul sebagai formula terpilih memenuhi 6,12\% ALG energi, 5,48\% ALG karbohidrat, 6,73\% ALG lemak dan 8,25\% ALG protein. Kandungan serat pangan dalam formula terpilih minuman kedelai dengan penambahan bekatul adalah 3,72 gram per 100 gram. Berdasarkan hal tersebut dapat disimpulkan bahwa per takaran saji minuman kedelai dengan penambahan bekatul $(275 \mathrm{ml})$ terkandung serat pangan sebesar 10,23 gram.

\section{KESIMPULAN}

Analisis kadar serat pangan menunjukkan F3 memiliki kadar serat pangan tertinggi sedangkan F0 memiliki kadar serat pangan terendah. Analisis aktivitas antioksidan menunjukkan bahwa F3 memiliki aktivitas antioksidan tertinggi sedangkan F1 memiliki aktivitas antioksidan terendah. Jika dibandingkan dengan cut off, seluruh formula minuman kedelai dengan penambahan bekatul memiliki aktivitas antioksidan yang rendah. Hasil uji organoleptik menunjukkan bahwa penambahan bekatul berpengaruh nyata terhadap warna, aroma, tekstur dan rasa minuman kedelai. Berdasarkan uji rangking didapatkan formula terpilih adalah F3. Per takaran saji formula terpilih (275 ml) memiliki kandungan energi 6,12 kkal, karbohidrat 5,48 gram, lemak 6,73 gram dan protein 8,25 gram. Kandungan serat pangan per takaran saji formula terpilih $(275 \mathrm{ml})$ adalah 10,23 gram. Berdasarkan BPOM, produk pangan dalam bentuk cair dikatakan memenuhi klaim kaya serat pangan jika mengandung serat pangan sebesar 3 gram per 100 gram. Hal tersebut menunjukkan bahwa formula terpilih telah memenuhi klaim produk kaya serat pangan.

\section{UCAPAN TERIMA KASIH}

Terima kasih kepada Tuhan Yang Maha Esa serta seluruh pihak yang telah membantu penulis sehingga penelitian ini dapat berjalan dan terselesaikan dengan baik. 


\section{DAFTAR PUSTAKA}

Alfira, A. (2014). Uji Aktivitas Antioksidan Ekstrak dan Fraksi Kulit Batang Sintok ( Cinnamomum sintoc Blume) (Issue September).

Aliyah, R. (2010). Pembuatan Es Krim Sari Wortel Terhadap Kadar Betakaroten dan Sifat Inderawi. In Skripsi, Fakultas Teknik.

Amir, Y. (2018). Daya Terima Susu Bekatul Sebagai Pangan Fungsional.

Aparecida, S., Faria, C., \& Bassinello, P. Z. (2012). Nutritional composition of rice bran submitted to different stabilization procedures. Brazilian Journal of Pharmaceutical Sciences, 48(4), 652-657.

BPOM. (2016). Peraturan Kepala Badan Pengawas Obat Dan Makanan Republik Indonesia Nomor 13 Tahun 2016 Tentang Pengawasan Klaim Pada Label Dan Iklan Pangan Olahan. Bpom, 1-16.

BPOM RI. (2016). Peraturan Kepala Badan Pengawas Obat dan Makanan Republik Indonesia Nomor 9 Tahun 2016 tentang Acuan Label Gizi. Badan Pengawasan Obat Dan Makanan Republik Indonesia, 1-28.

Fikri, Z., Nursalam, \& Misbahatul, E. (2010). Penurunan Kadar Kolesterol dengan Terapi Bekam. Penurunan Kadar Kolesterol Dengan Terapi Bekam (The Effect of Cupping Therapy on Cholesterol Reduction in Patients with Hypercholesterolemia) Zahid, 5(2), 195-200.

Hendrayati, H. (2019). Substitusi Bekatul Pada Pembuatan Biskuit Terhadap Peningkatan Kadar Serat Sebagai Jajanan Tinggi Serat. Media Gizi Pangan, 26(2), 171. https://doi.org/10.32382/mgp.v26i2.1026

Laokuldilok, T., F. Shoemaker, C., Jongkaewwattana, S., \& Tulyathan, V. (2010). Antioxidants and Antioxidant Activity of Several Pigmented Rice Brans. Journal of Agricultural and Food Chemistry, 59(1), 193-199. https://doi.org/10.1021/jf103649q

Luthfianto, D., Noviyanti, R. D., \& Kurniawati, I. (2017). Karakterisasi Kandungan Zat Gizi Bekatul pada Berbagai Varietas Beras di Surakarta. Jurnal Kesehatan, 2(1), 371-376.

Nadimin, N., Sirajuddin, S., \& Fitriani, N. (2019). Mutu Organoleptik Cookies Dengan Penambahan Tepung Bekatul Dan Ikan Kembung. Media Gizi Pangan, 26(1), 8. https://doi.org/10.32382/mgp.v26i1.991

Napitupulu, D. S., Karo-Karo, T., \& Lubis, Z. (2013). Pembuatan kue bolu dari tepung pisang sebagai substitusi tepung terigu dengan pengayaan tepung kedelai. Jurnal Rekayasa Pangan Dan Pertanian, 1(4), 14-19. https://www.karger.com/Article/FullText/162355

Nataliningsih. (n.d.). Analisis Kandungan Gizi Dan Sifat Organoleptik Terhadap Cookies Bekatul. 
nur hidayah budhi andriani, lutfi nurdiana asnindari. (2016). Pengaruh pemberian susu kedelai terhadap kadar kolesterol pada lansia hiperkolesterolemia di kedon bantul. Pengaruh Pemberian Susu Kedelai Terhadap Kadar Kolesterol Pada Lansia Hiperkolesterolemia Di Kedon Bantul.

Nur, R., Lioe, H. N., Palupi, N. S., \& Nuratama, B. (2018). Optimasi formula sari edamame dengan proses pasteurisasi berdasarkan karakteristik kimia dan sensori. Mutu Pangan, 5(2), 88-99.

Puspitasari, R. M. (2017). Perbedaan Kadar Kolesterol Ldl Pasien Puasa Dan Tanpa Puasa Di Rsud Salatiga. http://repository.unimus.ac.id/id/eprint/1245

Santoso, A. (2011). Serat Pangan (Dietary Fiber) Dan Manfaatnya Bagi Kesehatan. Magistra, 35-40. https://doi.org/10.1108/eb050265

Sari, E. Y., \& Husna, C. (2016). Gaya Hidup Dengan Kemampuan Mengontrol Kolesterol Pada Pasien Hiperkolesterolemia Di Rsud dr. Zainoel Abidin. 5. eka.yunita@mhs.unsyiah.ac.id\%0AHusna_psik_usk@yahoo.com

Selawa, W., Revolta, M., Runtuwene, J., Citraningtyas, G., Studi, P., Fmipa, F., \& Manado, U. (2013). Kandungan Flavonoid Dan Kapasitas Antioksidan Total Ekstrak Etanol Daun Binahong [Anredera cordifolia(Ten.)Steenis.]. Pharmacon, 2(1), 18-23. https://doi.org/10.35799/pha.2.2013.1018

Siburian, E. (2014). Penetapan Kadar Protein Pada Susu Kedelai Program Diploma Iii Analis Farmasi Dan Makanan. Tugas Akhir.

Siregar, R. N. I. (2015). The Effectof Eugenia polyantha Extrac on LDL. J Majority, 4(5), 8592.

Sookwong, P., Suttiarporn, P., Boontakham, P., Seekhow, P., Wangtueai, S., \& Mahatheeranont, S. (2016). Simultaneous quantification of Vitamin E, $\gamma$-oryzanols and xanthophylls from rice bran essences extracted by supercritical CO2. Food Chemistry, 211, 140-147. https://doi.org/10.1016/j.foodchem.2016.05.001

Triastini, M. C. (2018). Uji Aktivitas Antioksidan dan Kesukaan Panelis Terhadap Es Krim Sari Serai (Cymbopogon citratus (DC.) Stapf). https://www.jstage.jst.go.jp/article/amr/1/5/1_010501/_article/char/ja/\%0Ahttp://www.ghbook.ir/index.php?name=هلى ر ساذه ذذوي ن\&option=com_dbook\&task=readonline\&book_id=13650\&page=73\&chkhashk=ED9C 9491B4\&Itemid=218\&lang=fa\&tmpl=component\%0Ahttp://dx.

Tristantini, D., Ismawati, A., Pradana, B. T., \& Gabriel, J. (2016). Pengujian Aktivitas Antioksidan Menggunakan Metode DPPH pada Daun Tanjung ( Mimusops elengi L ). Universitas Indonesia, 2. 
Tuarita, M. Z., \& Sadek, N. F. (IPB/Fakultas T. P. (2017). Pengembangan Bekatul sebagai Pangan Fungsional: Peluang, Hambatan, dan Tantangan Rice Bran Development as Functional Foods: The Opportunities, Obstacles, and Challenges. Jurnal Pangan, 26(22).

Widyasanti, A., Rohdiana, D., \& Ekatama, N. (2016). Aktivitas Antioksidan Ekstrak Teh Putih (Camellia sinensis) dengan Metode DPPH (2,2 Difenil-1-Pikrilhidrazil). Journal Fortech, 1(1), 2016. http://ejournal.upi.edu/index.php

Wijaya, O. S. S. (2018). Aplikasi Uji Organoleptik Metode Cata (Check-All-That-Apply) Dalam Menggambarkan Karakteristik Puding Susu.

Wulandari, M., \& Handasari, E. (2010). Pengaruh Penambahan Bekatul Terhadap Kadar Protein Dan Sifat Organoleptik Biskuit. Jurnal Pangan Dan Gizi, 01(02), 55-62. https://doi.org/10.26714/jpg.1.2.2010.\%25p

Yani, M. (2015). Mengendalikan Kadar Kolesterol Pada Hiperkolesterolemia. Jurnal Olahraga Prestasi, 11(2), 115737. https://doi.org/10.21831/jorpres.v11i2.5749

Yoeantafara, A., \& Martini, S. (2017). Pengaruh Pola Makan Terhadap Kadar Kolesterol Total. Media Kesehatan Masyarakat Indonesia, 304. https://doi.org/10.30597/mkmi.v13i4.2132

Yulifianti, R., Muzaiyanah, S., \& Utomo, J. S. (2018). Kedelai sebagai Bahan Pangan Kaya Isoflavon. Buletin Palawija, 16(2), 84. https://doi.org/10.21082/bulpa.v16n2.2018.p84-93

Yunarto, N., Aini, N., Oktoberia, I. S., Sulistyowati, I., \& Kurniatri, A. A. (2019). Aktivitas Antioksidan serta Penghambatan HMG CoA dan Lipase dari Kombinasi Ekstrak Daun Binahong-Rimpang Temu Lawak. Jurnal Kefarmasian Indonesia, 9(2), 89-96. https://doi.org/10.22435/jki.v9i2.1930 